\title{
The New Developments of Constructivism Theory and Its Reflection on College English Teaching in the Era of New Media-A Case Study of International Textile Trade English
}

\author{
Jinzhu Zhang \\ School of Foreign Languages, Tianjin Polytechnic University, Tianjin, China \\ Hongquan Lin \\ Personnel Department, Tianjin Polytechnic University, Tianjin, China
}

\begin{abstract}
Constructivism, as one of the core theory of psychology, has a deep influence on foreign language teaching and learning in China. The author in this paper takes a university-based ESP course, International Textile Trade English as a case study and applies the main conception of the four schools of Constructivism as a guide to organize teaching practice, with the expectation to explore the effective combination of Constructivism theory with the ESP teaching practice. Some limitations of the research are put forward in the end.
\end{abstract}

Index Terms-constructivism theory, ESP course, international textile trade English, teaching practice

\section{INTRODUCTION}

In 1980s, some western psychologists, such as Piaget, established a Constructivism learning theory based on cognitive learning theory. Since then, the research on Constructivism has become the popular topic in the fields of psychology and education. Constructivism, which emphasizes the individual construction of the learning process and believes that learners would always bring personal meaning into the cognitive process. The process of learning is an active construction rather than the mere passive acceptance of information outside based on their own knowledge and experience. In other words, students' learning is the process of establishing a new cognitive structure, exploring and communicating actively in the context created by teachers with the help of existing knowledge and experience.

Constructivism theory emphasizes the student-centered teaching conception. Students are the main body of learning, the subject of cognition and information processor, and the active constructor of knowledge meaning. Teachers are the organizers, guides and promoters in the process of learning. It emphasizes the initiative, practicality and creativity. Constructivism of learning is actually a metaphor for learning in essence which Compares knowledge acquisition to the process of architecture or construction (Fox, 2001). Constructivism Theory has its important guiding significance for foreign language teaching and research in China. In this paper, the author would like to illustrate its influence on the course construction, teaching content and mode on the course of Textile trade English at Tianjin Polytechnic University in China.

\section{LITERATURE REVIEW}

The study of Constructivism learning theory started quite late in China. He Kekang (1998) is the first scholar in China who introduced Constructivism learning theory. in recent years, the research on English teaching based on Constructivism has increased significantly. Hou Wanchun(2000) points out that Constructivism is not only a philosophical concept, but also a teaching concept, which is different from the traditional teaching concept and has great implications on foreign language teaching. Jia Luyi (2007) carries out Constructivism principles in news English teaching, which emphasizes the student-centered teaching and active meaning construction, helps students expand their thinking, find and solve problems through cooperative learning. Wang Zheng(2014) aims to provide enlightenment for normal classroom teaching of College English by selecting representative teaching examples to explore classroom teaching from the perspective of cognitive-social construction based on the literature review of Constructivism learning theory.

Since 1990s, the emergence of audio-visual classroom, multimedia computer simulation laboratory, electronic library has greatly promoted the vigorous development of multimedia English teaching. Many scholars have carried out multimedia English teaching research based on Constructivism. Zhang Xiaoying, Li Tianxian(2002) discuss the multimedia College English teaching model based on Constructivism theory, including classroom teaching model, 
individualized teaching Model and network teaching model. Huang Ruoyu (2000) believes that Constructivism theory which advocates learner-centered learning methods and individualized and personal meaning construction, has important guiding significance for multimedia foreign language teaching and the establishment of its model. Ding Gang (2003) proposes that the realization of Constructivism teaching mode requires a variety of conditions, which the traditional classroom teaching in China can not provide. Only in the web-based teaching environment can a Constructivism learning environment for foreign language be established.

These studies have promoted the development of foreign language education in China, but research on a combination of Constructivism theory with more specific branches of College English teaching is not carried out. Such as the Textile Trade English. The university that the author works is a multidisciplinary university in China with the major characteristics of Textile Engineering. In China, textile industry has played an important part in national economy and textile trade has enjoyed a large proportion in Chinese international trade. International Textile Trade English is a very professional and important branch of ESP, English for special purposes. ESP is the English courses offered by colleges and universities for non-English majors. The ultimate goal of ESP teaching is to lay a solid foundation for students to carry out academic research and exchange activities in professional fields, and to help students prepare well in these fields and aspects and to enable students to conduct oral and written English expressions and academic exchanges skillfully. Sun Youzhong (2011) states that what to teach and how to teach are the very fundamental problems that College English reform has to deal with, CBI (content-based instruction) and ESP (English for special purposes) are the general directions of College English education reform in terms of the teaching content, which enables the educators to realize the three aims of College English education, they are: the knowledge construction, thinking cultivation and English proficiency improvement.

But so far, the author enters the key words of International Textile Trade English and Constructivism in CNKI (China National Knowledge Internet, the largest research database in China), there is little research on International Textile Trade English teaching based on Constructivism theory. In addition, the existing studies do not pay much attention to the division of Constructivism schools. Most of them expound the research of foreign language teaching under the guidance of Constructivism, but the study of combining foreign language teaching with a certain school of Constructivism theory has hardly given any consideration to this.

Based on the views of the four basic schools of Constructivism, this paper probes into the multimedia International Textile Trade English teaching from four aspects: the development of language thinking ability, situational teaching, interactions to promote the learning and the real task learning. The research aims to stimulate students' interest in learning, improve their autonomous language constructing ability, speculative and expressive ability.

It is a requirement from every side involved to explore the diversity and innovation of College English education in the new era of informatization, because many studies and survey indicate that all the participants of College English teaching are not quite satisfied with the achievements of College English teaching, there is a huge gap between the supplies and demands of College English education. That is the reason why the author chooses a university-based ESP course as the research topic and tries to explore a more efficient way of university-based ESP teaching, thus meeting the actual needs of students' future career development and making contributions to the advancement of College English education reform.

\section{RESEARCH DESIGN}

There are many schools of thought and many branches since the emergence and development of Constructivism, but all of them can be traced back to its sources, which can be divided into four basic schools: the Piaget school, the Vygotsky school, the social Constructivism school and the holistic Constructivism school (Green; Gredlern, 2002). In this part, the author deigns the research and classroom teaching based on the four schools of the Constructivism.

\section{A. Subjects}

Eighty-eight English learners from School of Textile Engineering at TJPU were selected as the subjects for the study. All of them have received the one-year general College English courses, Most of them had got the scores above 425 points in CET-4. Among the five specialties that students from School of Textile Engineering at TJPU are entitled to select, all these 88 students choose the International Textile Trade as their future career, which indicates that all these 88 students after graduation will work in international trade which mainly deals with the textile products home and abroad. English can be a communication tool and working language for their future daily work. Meanwhile, they are the professionals of textile industry, they specialize in textile and are the experts on the field of textile as well as the proficient users of English. Therefore, many of them are highly motivated in studying English. Because it is a big and serious decision that they have to make before taking the English as their working language in the future. Many of them have their future professional and academic goals through learning English and achieving a relatively higher degree of communicative competence. To some extent, the conception that English serving as a tool of future career tends to be more realistic than that of English majors.

All the 88 students are divided into 3 classes (Class A, Class B, Class C) based on their English scores of CET-4, and a specially designed oral and listening test. The reasons why the author did so are as follows. Although they are highly motivated and are comparatively more proficient than their peers in terms of their language skills and expressive 
abilities, there is still a large gap between the highly proficient and relatively poor learners, especially in terms of their knowledge about trade and skills of listening and speaking. Many of them are quite skillful in doing exercises and passing exams, while the phenomenon of the Dumb and deaf English is similarly serious among these English learners who are originally educated as a professional of engineering, these problems may become more evident when they are learning the ESP courses which are not targeted to pass the exams, such as International Textile Trade English.

\section{B. Research Design}

\section{Application of Piaget School to develop language thinking ability}

Piaget school believes that learning should be realized through the learners' high-level thinking activities, and learning is a process of active construction. It is the activity of students to construct their own knowledge the construction of which is not only the construction of the meaning of new information but also the transformation or reorganization of the original experience.

In order to effectively improve the pertinence and effectiveness of International Textile Trade English teaching and promote the training and improvement of students' thinking ability, the author conducted a one-year practice and exploration of International Textile Trade English at school of textile engineering. The course of International Textile Trade English is given for 2 semesters with 4 classes each week. Although as the ESP course learners, there is still a wide gap between the expected teaching targets and real situations of students' learning. Therefore the total 120 classes are divided into several procedures, they are the improvements of language proficiency regardless of the specialty of International Textile Trade, which aims to lay a solid foundation for the learning of major English; the improvements of thinking ability and critical and logical thinking by reading a variety of English newspapers and magazines related to the economics and trade; the instructions of International Textile Trade English covering the fields of exporting and importing, marketing and negotiating, etc. And each process with specific teaching aims is not strictly divided and separated in the teaching practice.

Correspondingly, different teaching targets are set for different classes. As for the students in class A, they are expected to become a proficient English learners who have laid a solid foundation for English learning and have accumulated enough language input and abundant language output as they are required. More importantly, they are expected to grasp the basic theory related to the international trade and capable of dealing various marketing and negotiating situations by using English as their working language. To some extent, they are expected and trained as half English majors although their major is more concerned about textile engineering.

In teaching practice, the 30 students of class A have a solid foundation of English, active thinking and strong ability of self-study. The author uses English as much as possible to teach difficult professional core articles. In the process of teaching, students are the main body. Teacher serves as the guidance. As for the teaching tasks, the author increases the difficulty of the reading materials and highlights the professional characteristics of textile and international trade. The author requires students to collect relevant reading materials related through the network, helps students expand their vocabulary related to international trade and textile industry. To train students' ability to read fast and increase the proportion of economic and business English listening and speaking, the author uses multimedia technology to conduct classroom English listening and speaking training through English movies, videos, VOA fast listening materials and so on.

The training of four skills is carried out in the whole teaching practice. In the first stage of teaching, the author chooses some reading materials related to economy and international trade from many different media sources and hands them out before class, they are required to read and get the general ideas and write them out. Then the author would guide them to penetrate and probe into the materials by asking questions in and beyond the passages. Students are required to answer in English with critical and logical thinking reflected. The main forms of the classroom learning are the preview check, teacher's instruction guided by questions and students' group discussion and presentation. A group project will be requested to finish during a certain period, and the performance of the presentation will be considered in the final scores. The teaching efficiency of each stage will be tested by a systematic exam with reading and speaking, the general scores of the exams will decide whether the author will come to the next stage and whether the materials that the author offers are scientific and effective enough to help students improve their language proficiency.

As for the 31 students in class B, they are less proficient than their peers in class A. based on their individual differences in language skills, different teaching aims and teaching procedures are set for them. In the first and second stage of the teaching process, the author adopts a compromised method, that is, bilingual teaching in English and Chinese, and carry out the teaching step by step around the teaching content that are handed out to them before class. The author spends more time providing learning scaffolding to these students by using the campus network learning platform to achieve the sharing of teaching resources, students are required to prepare problems related to the content of teaching after class. At the same time, students are encouraged to make full use of the network, collect relevant information, expand their professional knowledge and master a large number of technical terms through the first and second stage of classroom teaching and training. The reading tasks offered to them are not very challenging. They are required to get the general ideas and share them with us. For this group, special attention is given to their basic language skills. When the first period finishes, a different examination is given to them. 
As for the 27 students in class C, although they have passed the CET-4 and have chosen the major of International Textile Trade, they are less motivated and proficient compared with the two classes above. The set teaching targets for them would be relatively lower compared with the other two classes. In class C, a set of textbooks are used in teaching practice, which would help them focus and get a clearer learning targets. In teaching practice, the author mainly leads them to read and explain in details to them, and encourages them to get a clearer aim for their future development and use a wide range of internet and information resources to improve their English. Meanwhile, the author helps them learn and use the basic business English and accumulate the special terms gradually.

For all students in three classes, a general and basic requirement of taking learning diaries is given to them, this aims to train students to monitor learn and reflect on the learning process by themselves. And there are some requirement differences as for the amount of the notes and the content. The author collects the notebooks and give a score for students notes, and the score of the notes will be considered in the final exams.

Piaget school believes that the construction of knowledge is conducive to the cultivation of human thinking ability, but also is subject to the thinking ability of each student in intelligence or other aspects of the individual differences. The differences in English listening, speaking, reading, writing and other skills are particularly prominent. Therefore, in the new media era, according to the Piaget school theory, a grading and relatively individualized classroom teaching is preferred, which fully respects the individual differences and learning needs of students. Through the use of microcourses, Moocs and mobile phone teaching app (such as LanMo Clouding Classroom) Wechat, QQ and other personalized teaching resources, the educators can effectively improve the language thinking ability of students and enrich students' English knowledge Reserve and realize the all-round development of students at all levels.

2. The Application of situational teaching advocated by the Vygotsky School

Vygotsky (1964) concludes from the point of view of historical culturology that human beings' ability to internalize social culture determines the advanced thinking activities. And this thinking system is not infinite and unchangeable. Vygotsky emphasizes that social culture determines people's thinking activities, human cognitive ability is developing and changing, and cognitive ability is closely related to social culture. The external world can not only be recognized, but also be constructed. Constructivism believes that the construction of knowledge is influenced by time, space and environment, knowledge loses its authenticity and learning For learners is meaningless when it is separated from the three elements above. Meaningful learning is marked by experiential situational forms. Therefore, situational teaching is more effective than abstract regular teaching. Wu Xiaoyan (2006) thinks that social situation is an important resource for learners' cognition and development. It is emphasized that learning must exist in a specific environment, and attention should be paid to the role of learning environment in learning. Knowledge is acquired through the construction of meaning in a certain situation. The creation of the situation in the learning environment must be beneficial to the construction of the students' meaning.

In the teaching practice of the university-based International Textile Trade English, it is an effective teaching form for students to create a learning environment close to the actual business situations by relying on multimedia technology. Frankly speaking, it is huge challenge not only for teachers as well as for students to learn English in Chinese context without the knowledge of needs in the future working environment. With the advancement of information technology, the teaching of College English has been revolutionized in terms of the teaching concept, learning materials and teaching curriculum and methods. one of the greatest advantages of multimedia technology is the easy acquisition of the authentic and simulated learning materials and the creation of learning environment.

In the second and third stage of teaching practice, the author searches from internet and uses the authentic case studies of international trade and negotiations, especially the resources from Moocs and Micro-courses. All of these resources can redeem the disadvantages of empty talk in classroom teaching and makes classroom teaching more interesting. More importantly, students can fully get involved in the teaching and learning and autonomous active learning can be enhanced and fully promoted. What has to be emphasized in teaching practice is the gathering of authentic trade cases and the accumulation of language ability. China, as the largest exporters and textile manufacturing in the world, has enjoyed great reputation among the world. Many private-owned enterprises in south China have accumulated successful experience in textile international trade. One professor from the School of Textile Engineering have published a masterpiece about the International Textile Trade in Chinese, the author serves as the helper for the professor to collect the successful cases of international textile trade during the process of its publication. This meaningful experience and the first-hand materials accumulated is quite helpful in teaching practice. According to the needs of English language teaching, the material is modified and arranged appropriately, which can ensure that the material of situational teaching can come from working practice by integrating the required knowledge of International Textile Trade English into each situation. A basic principle is to ensure that the teaching content is consistent with the actual working tasks, so that the situation becomes a link between teaching language knowledge and developing the ability of application. This kind of situational teaching has a clear guiding effect on the handling of similar cases in future work.

Vygotsky emphasizes, knowledge is created and applied in a particular situation. situational teaching is to refine teaching subjects which should highlight the authenticity and relevance. for example, the case reports and analysis on the brand Li Ning Clothing in 2018 International Fashion Show, Anti-dumping investigation against Chinese clothing, 
the establishment of clothing manufacturing companies in Southeastern Asian countries, or the successful marketing cases of NIKE or ADIDAS, etc. There are plenty of English resources online about these topics.

In the case studies, the author gives full play to the role of the multimedia language laboratory, and the "multimedia projector plus large screen" equipment has the basic conditions of computer-aided teaching and it is also the main form of multimedia classroom teaching mode dominated by teachers, the author uses computer teaching software and various audio-video equipment to present teaching contents. Students are required to take an active part in the training of all kinds of virtual situations in spoken International Textile Trade English. This teaching content and training method are closely related to the actual business situation of international textile trade, which is helpful to improve the students' communication ability in professional English.

The use of simulated multimedia business situations can break the limitation of time and space, and students can directly enter the virtual business situations and the vivid language environment, which in reality is difficult to realize. Not only can the professional knowledge of textile trade English be mastered quickly, but also can make an intuitive impression on students how to use English learned in class. Therefore, the multimedia language laboratory has the function of creating rich language learning situations to provide a realistic training environment for students to learn. Students are able to master the professional knowledge of international textile trade firmly, and effectively improve the cognitive ability and the application ability of international trade English.

3 . The application of interactive learning advocated by Social Constructivism

Williams (2000) and Burden (2000) propose the social Constructivism theory based on the cognitive theory, humanism and social interaction. The theory of social Constructivism, which emphasizes social interactive learning, holds that social situation is an important resource for learners' cognition and development, and advocates that learners can construct a "learning community" to interact. Zhao Dongyun (2005) proposes that learners should communicate with their classmates in the language environment of classroom teaching. To improve one's language ability by influencing students and accepting their influence at the same time.

Social Constructivism emphasizes "cooperation" and "conversation", that is to say, students are required to participate actively in classroom discussions and communicate with each other in trade English on the basis of equal dialogue between teachers and students. Teachers should support "teacher-student" and "student-student" cooperation and communication. Teachers are expected to design more open questions and themes and provide students with opportunities to participate in the classroom learning. this interactive teaching can enhance communication between teachers and students, give students the opportunity to explore ways to solve problems, meanwhile, learn to respect the views of others and the ways to cooperate with others. for example. In International Textile Trade English teaching, the author sets the first 15 minutes of class as "free talk" in order to avoid "monologue" or "chorus". The main content is news reports, major events at home and abroad, social hot spots, students present what they have noticed or been interested with the help of PPT by searching the multimedia network information. The form of PPT presentation in class consists of a personal talk, a two-person dialogue, a storytelling, a group discussion, a class debate, etc. There are 3-4 people in the group discussion. The interactive teaching method of integrating the hot topics or topics of interest into the classroom can enhance the students' desire to participate. At the same time, it also activates the classroom atmosphere, and increases the interaction between students and teachers and the opportunity of learning through the collision of different perspectives. It deepens students' understanding of the problems or subjects, and makes the teaching become a creative process in which the students take the initiative to take part in the development of their individuality.

The teaching model of group interaction can arouse the students' learning enthusiasm, let students learn from each other and find problem solving in interaction and promote students' team learning through collaborative learning, ultimately achieve the meaning construction of what they have learned.

4. The application of the real task advocated by Holistic Constructivism

The theory of holistic Constructivism focuses on the cultivation of comprehensive competence from the perspective of "wholeness", which is characterized by the implementation of holistic Constructivism theory of teaching and emphasis on the conception that learners' learning must begin with an overall understanding.

In the context of practical application, the main goal of the holistic Constructivism of language learning is to make learners pay attention to the learning process and learning results. The role of teachers is to create and organize challenging learning tasks and to ask exploratory questions, thus facilitating learners to rethink their viewpoints. the creation of learning tasks is to meet the needs of each student in each new learning environment. The "task" of language learning is the activity of students to achieve a certain goal. In order to create a learning environment with real tasks, expand the students' professional knowledge, and create a favorable language learning atmosphere, Teachers are expected to be good at making use of multimedia teaching methods to express the monotonous language and characters in a concrete and attractive way, and use The courseware, which combines audio, video, graphics, text and other lifelike performance props, can greatly impact students' senses, activate the students' thinking, arouse the students' interest, and enhance the students' understanding and memory of knowledge in the lively, interesting and relaxed learning atmosphere. Students can devote themselves to learning, experiencing the fun of learning, and enhancing their desire to learn the real tasks.

In teaching practice of the International Textile Trade English, the authenticity is highly valued. The gathering of authentic learning materials can only be achieved with the help of Internet and information technology. It is a difficult 
but rewarding teaching experience. Such as the real case of business negotiations in international trade, a presentation of new products, or a contract negotiations, etc. The author firstly shows the video clips to students and make sure that they have fully understood the content, some key words and special terms are offered to them in advance. And then, students in groups are expected to simulate the situations with different roles. After that, a peer review and evaluation will be made.

After class, students are required to review the relevant teaching contents in an all-round way according to the learning tasks assigned in class, to inquire about relevant materials on Internet, and to make PPTs according to the problems. It can be seen that it is very important to set up reasonable tasks in teaching practice. It is helpful for students to understand and master the learning content. Holistic Constructivism theory of learning pays special attention to creating the real tasks, which has enlightening significance for the cultivation of students' language communication ability.

Modern information technology, especially network technology, makes English teaching not limited by time and place. The development of multimedia technology with the direction of autonomous learning has greatly changed the single traditional teaching method. More autonomy, openness and creativity are the typical characteristics of the foreign language teaching in the era of informatization. The autonomous manipulation and cognitive simulation, not only greatly enrich the teaching content and broaden the cognitive channels, but also renew the educational concept. Teachers in new era are expected to give full play to the advantages of multimedia, stimulate students' interest in learning English and improve teaching efficiency.

Constructivism teaching theory holds that learning should be characterized with situationality, sociality and autonomy. Learners are the active constructor of knowledge meaning. Teachers are helpers and promoters of students' meaning construction. The author believes that the design of teaching model with a combination of Constructivism theory and the practice of International Textile Trade English will be the developing trend of international trade English teaching and research, or more broadly, the university-based ESP teaching at university levels.

\section{LIMITATION AND CONCLUSION}

As a new ESP course with the university-based characteristics, the teaching practice of International Textile Trade English is still at the experimental stage at the author's university. There is no fixed teaching model and content to imitate in China, more importantly, the author, as a teacher without educational background of textile engineering, to some extent, is not fully qualified to teach such as course with engineering background. But its nature firstly manifests its language characters, which undoubtedly should follow the rules of language teaching and learning. And secondly, the author, as the teacher of the course, is quite willing to make efforts to learn and to share through teaching.

More importantly, the theory of Constructivism has provided the basic conception and guidance of teaching.

In the authors' teaching practice, students in three classes have both made progress and acquired every skills related to international textile trade. as the scores of each class and the interviews for students have indicated(due to the limitation of the paper, the data, exam papers and the interview results will not be provided in this paper).

Besides, multimedia has become the most convenient tool for students to acquire knowledge and information. This kind of teaching environment in the era of new media can effectively cultivate students' language abilities and skills in future working place. The full use of multimedia audio-visual means in teaching has fully embodied the concept of student-centeredness. The essence of Constructivism, which turns "teaching" into "learning" by using various multimedia techniques in language teaching, has fully reflected the theoretical essence of educational psychology. Under the guidance of the Constructivism learning theory, the author believes that an effective foreign language teaching should be like this: learners autonomously construct their meaning of the content in an interactive learning environment, in which teachers provide students with a variety of various authentic language input serve as the scaffold and guide rather than instructor. And it is expected that more empirical research can be carried out on the reflection of the Constructivism learning theory on the foreign language teaching, especially the university-based ESP teaching practice.

\section{REFERENCES}

[1] Ding Gang, Liu Lei. (2003). Constructivism and Web-based Foreign language Teaching. Audio-Visual Teaching of Foreign languages 54.10, 35-43.

[2] Fox. (2001). Constructivism examined. Oxford Review of Education 23. 1, 58-67.

[3] Green, S. K. \& M. E. Gredler. (2002). A review and analysis of Constructivism for school-based practice. School Psychology Review 31.2, 236-252.

[4] He Kekang. (1998). Constructivism-the theoretical basis for innovating traditional Teaching. Course Education 31, $3.18-26$.

[5] Huang Ruoyu. (2000). Constructivism and multimedia foreign language teaching model. Audio-Visual Foreign language Teaching 45, 6. 31-38.

[6] Hou Wanchun. (2000). Constructivism teaching concept and college foreign language teaching. Journal of Sichuan Institute of Foreign languages 43, 7. 25-32.

[7] Huang Yuanpeng. (2013). Translation teaching from the perspective of's Constructivism. Foreign Language World 63, 6. 43-48.

[8] Jia Luyi. (2007). Journalism English Teaching under the guidance of Constructivism Teaching Theory. Journal of Xinzhou normal University 36, 10. 28-33. 
[9] Piaget J. (1966).The Origins of Intelligence in Children. New York: International Universities Press.

[10] Sun Youzhong, Li Liwen. (2011). CBI, ESP \& the future trend of college English reform in China. Foreign Language Research 32, 5. 1-4.

[11] Vygotsky, L.S. (1964). Mind in Society. Cambridge: Harvard University Press.

[12] Wu Xiaoyan. (2006). Enlightenment to English Teaching from Constructivism Theory. Foreign language and Foreign language Teaching 43, 2. 13-17.

[13] Wang Zheng. (2014). effective College English Teaching in the context of's Constructivism Teaching Theory. Foreign language world 72, 3. 34-37.

[14] Williams, M. \& R. L.Burden. (2000). Psychology for Language Teachers. Beijing: Foreign Language Teaching \& Research Press.

[15] Zhao Dongyun. (2005). Examine the foreign language teaching in China from the perspective of social Constructivism. Journal of Qiqihar University 35, 5. 47-52.

[16] Zhang Xiaoying, Li Tianxian. Constructivism Theory and Multimedia Computer-aided College English Teaching. AudioVisual Teaching of Foreign languages 48, 4. 68-74.

Jinzhu Zhang, Male, lecturer at School of Foreign Languages of Tianjin Polytechnic University, Tianjin, China. His research interest lies in the Applied Linguistics and Language Testing Theory \& Practice.

Hongquan Lin, Male, associate professor at Tianjin Polytechnic University, Tianjin, China. His research interest lies in the Information Management and Information System, Personnel Management. 